University of Nebraska - Lincoln

DigitalCommons@University of Nebraska - Lincoln

USDA National Wildlife Research Center - Staff Publications
U.S. Department of Agriculture: Animal and Plant Health Inspection Service

January 2001

\title{
Introduction to Pesticides and Wildlife
}

John J. Johnston

APHIS/WS/National Wildlife Research Center, U.S. Department of Agriculture

Follow this and additional works at: https://digitalcommons.unl.edu/icwdm_usdanwrc

Part of the Environmental Sciences Commons

Johnston, John J., "Introduction to Pesticides and Wildlife" (2001). USDA National Wildlife Research Center - Staff Publications. 589.

https://digitalcommons.unl.edu/icwdm_usdanwrc/589

This Article is brought to you for free and open access by the U.S. Department of Agriculture: Animal and Plant Health Inspection Service at DigitalCommons@University of Nebraska - Lincoln. It has been accepted for inclusion in USDA National Wildlife Research Center - Staff Publications by an authorized administrator of DigitalCommons@University of Nebraska - Lincoln. 
Published in Pesticides and Wildlife, edited by John J. Johnston. ACS Symposium Series 771. American Chemical Society, Washington, DC, 2001. 


\title{
Chapter 1
}

\section{Introduction to Pesticides and Wildlife}

\author{
John J. Johnston
}

\begin{abstract}
APHIS/WS/National Wildlife Research Center, U.S. Department of Agriculture, 4101 La Porte Avenue, Fort Collins, CO 80521-2154
\end{abstract}

A pesticide is a substance intended for destroying, repelling or mitigating any animal, microorganism or plant pest. While pesticides are commonly chemical agents, biological or physical agents can also be pesticides. Many people equate the term pesticide with insecticide. However, there are a plethora of pesticides for which insects are not the target pest. Examples include herbicides, fungicides, rodenticides, acaricides, larvacides, etc. Additionally, pesticides are not limited to toxicants, but also include repellents, attractants and growth regulators (1).

Pesticides are nearly ubiquitous in today's world. In agriculture, insecticides, nematicides and herbicides are applied to plants and soil to improve the yield and/or the appearance of the harvested commodities (2). Such uses are common knowledge among the populace. A variety of other uses of pesticides are less obvious to the average citizen, but are widespread nonetheless. For example, insecticides and rodenticides are released into the environment in an effort to decrease populations of pathogen carrying animals such as insects and rodents. Pesticides such as mildicides and insecticides are routinely incorporated into building materials and/or applied to structures to prevent pest infestation. Pesticides are routinely applied to boat bottoms to prevent the attachment and growth of a mollusks. The list goes on and on.

The ubiquitous nature of pesticides suggests that exposure to wildlife is inevitable. Primary exposure results from wildlife directly consuming the pesticide formulation. Primary exposure scenarios include birds feeding on granular insecticide formulations, squirrels consuming rodenticide baits intended for rats, or wildlife being exposed to pesticide drift resulting from the spray application of an insecticide in an agricultural situation. Secondary exposure results from the consumption of animals containing pesticide residues. Secondary exposure scenarios include scavenging mammals such as ferrets, feeding on rodent carcasses containing rodenticide residues. Tertiary exposure results from another animal such as a raptor feeding on the secondarily exposed ferret in the previous example. Unfortunately, the possible routes of non-target exposure of wildlife to pesticides are varied and many.

Pesticides are bioactive compounds. As such, pesticides exert biological effects on living organisms (3). Fortunately, most pesticides are somewhat selective. The 
intended effect of the pesticide is usually more pronounced towards the target species than non-targets. Selectivity can also be enhanced by adopting application practices to minimize non-target exposure. However, even in the best of situations, selectivity is less than absolute. Thus, when non-target wildlife are exposed to pesticides, unintended biological effects often follow.

\section{Historical Perspective}

\section{Insecticides}

Even after Rachael Carson's Silent Spring (4) focused international attention on the deleterious effects of pesticides on wildlife, the scientific community was shocked to learn that insecticide residues had been discovered in penguins and seals in the Antarctic. The fact that these animals were located thousands of miles from the nearest pesticide application site illustrated to many that pesticide transport throughout the environment was widespread. In response to such findings, during the later half of the 1960's, the Canadian government collected and analyzed a variety of wildlife including mammals, fish, migratory and non-migratory birds, and invertebrates for pesticide residues. The results indicated that nearly every sample of Canadian wildlife contained detectable levels of pesticides. Furthermore, many of these pesticides were linked to declines in bird and fish populations, illustrating that unintended effects of pesticides on wildlife may be quite significant (5). As a result of these and additional studies, many of the popular pesticides of the era, such as DDT, were banned from use in Canada and the U.S.(6). Nearly 30 years after being banned, studies presented in this book such as "Bioaccumulation of Pesticides in Bats"(Chpt. 6) indicate that organochlorine pesticides are still present in U.S. wildlife. Additionally, "Tsetse and Locust Control in Africa"(Chpt. 7) points out that organochlorine pesticides are still being used in third world countries.

In the 1970's, the use of organophosphate and carbamate insecticides increased significantly. These insecticides were thought to be environmentally safer because they are less stable and less prone to widespread transport and bioaccumulation in the food chain. However, as pointed out in the chapters "Carbofuran Spill Site on a Remote Island of the Hawaiian National Wildlife Refuge"(Chpt. 3), "Forensic Investigations of Impacts from Three Groups of Pesticides on Raptors"(Chpt. 4) and "Chemical and Biochemical Evaluation of Swainson's Hawk Mortalities in Argentina" (Chpt. 21), organophosphate and carbamate insecticide exposure to non-target wildlife is not uncommon and can result in acute toxicity to significant quantities of wildlife.

In the 1980's, the next class of major insecticides, pyrethroids, was introduced. Even though pyrethroids have become widely popular, reports of non-target poisonings have been minimal. It appears that for pyrethroids, non-target wildlife poisonings are less of a concern than with previously the cited classes of insecticides.
However, pyrethrum, the biologically active chrysanthemum extract which pyrethroids are based upon, is toxic to reptiles as illustrated in the chapter on the development of toxicants for brown tree snake control on Guam (Chpt. 16).

\section{Herbicides}

Another major class of pesticides addressed in this book is herbicides. Potential wildlife exposure is significant because herbicides represent the most rapidly growing class of pesticides in the last two decades. Further contributing to the potential exposure of wildlife to herbicides is that these pesticides have been developed for application at multiple stages of agricultural production. For example, preplanting herbicides are applied to the soil prior to seeding, preemergent herbicides are applied prior to the appearance of the pest plants and postemergent herbicides are applied after the crop or weeds are visible. Due to the high level of research and development in this area, herbicides are composed of a wide variety of chemical classes. In general, herbicides tend to be more water soluble than most other types of pesticides. Potential wildlife exposure via herbicide contaminated surface water is a concern. Such concerns are addressed in the chapter "History and Risk Assessment of Triazine Herbicides in the Lower Mississippi River"(Chpt. 17).

\section{Rodenticides}

Rodenticides are used to reduce pest rodent populations in many countries. Though rodenticides are less widely used than insecticides or herbicides, non-target wildlife exposure to rodenticides is a significant concern due to similarities in the physiology and behavior of the target species and non-target wildlife. With rodenticides, development of safe application practices is extremely important to reduce non-target exposure. Several chapters in this text (Chpts. 11-14)address the development of safe rodenticides and the assessment of rodenticide related risks to non-target wildlife.

\section{Avicides}

Avicides are used to reduce pest bird populations. That such pesticides exist is a surprise to many people. Similar to rodenticides, a challenge for the development and safe use of avicides is to minimize potential exposure and toxic effects to non-target birds and other animals. In addition to the development of selective chemicals, as is the case with rodenticides, careful application is required to reduce exposure of nontarget species. Such approaches are presented in the chapter on bird preferences for multiple diets (Chpt. 3). Newly developed risk assessment approaches are applied to the use of an avicide in the chapters "Primary and Secondary Hazards associated with 
the use of Avicides"(Chpt. 15) and "Use of a Poisson Distribution to Estimate Blackbird Mortality from Pesticide Application"(Chpt. 8).

\section{Analytical Chemistry}

Chemical analyses are generally required to unequivocally determine the magnitude of pesticide residues in the environment. Without such techniques, determining pesticide exposure to wildlife is speculative at best. While approaches and analytical techniques to quantify pesticide residues in wildlife are contained in many chapters, these topics are covered in detail in "Ion Trap GC-MS Analysis of Tissue Samples for Chlorinated Pesticides", "Recent Advances in Analytical Techniques to Investigate Pesticide Poisoning in Wildlife", "Environmental Specimen Banking - a Useful Tool for Retrospective and Prospective Environmental Monitoring" and "Chorioallantoic Membranes for Non-lethal Assessments of Pesticide Exposure and Effects"(Chpts. 18-20). Similarly, new approaches for assessing the affects of pesticides on wildlife populations are contained in many chapters, but is the main topic of "Large Scale Monitoring of Non-target Pesticide Effects on Farmland Arthropods in England"(Chpt 5).

\section{Protecting Non-target Wildlife}

Finally, this book concludes with what may be the most important chapters, ways to protect wildlife from unintentional pesticide exposure. "Comparisons of Primary and Secondary Repellents for Aversive Conditioning of European Starlings"(Chpt. 22) describes studies to develop bird repellents. These repellents could potentially be used in lieu of avicides to protect agricultural commodities or could be added to pesticide formulations to minimize consumption by non-target birds. Regulatory aspects of protecting wildlife from pesticides are presented in "Hurdles in Compiling Pesticide Registration Incidents" and "Regulatory Aspects of Protecting Endangered Species with County Pesticide Bulletins”(Chpts. 24,25)

\section{References}

1. Toxicology: The Basic Science of Poisons; Amdur, M.O.; Doull, J; Klaassen, C.D., Eds.; McGraw Hill; New York, 1993.

2. Pesticide Effects on Terrestrial Wildlife; Somerville, L.; Walker, C.H., Eds; Taylor \& Francis Publ.; London, 1990.

3. Merriam Webster's Collegiate Dictionary; Mish, F.C.; Morse, J.M., Eds; Merriam-Webster Publ.; Springfield, MA, 1993.
4. Carson, R. Silent Spring; Houghton-Mifflin Publ., Boston, MA, 1962

5. Pesticides \& Wildlife. Canadian Wildlife Service, Ministries of Fisheries and Forestry; Ottawa, Canada, 1971.

6. Johnston, J.J. Toxicity of the Organophosphate Insecticide Fenitrothion and Its Metabolism by Blue Crabs, Callinectes sapidus. Ph.D. dissertation. Univeristy of Florida; Gainesville, FL, 1986. 